\title{
各種サンドイッチパネルの曲げ試験
}

\author{
正会員 飯 塚 五. 郎 蔵*
}

\section{\$1. 実験の目的}

サンドイッチパネルは 2 種以上の材料在重悋て接着 儿、個々の材料では得られないすぐれた性質をもたせよ うとするもので、特に表板として強度、外観のすぐ礼た もの起配し、コア（中間居）に海軽くて断熱、遮音性な ぞをもつものを入れる。乙れ江よつて強さ、機能、仕上 の3要素をが放た構造パネルか形成される。その使命は 建物の軽量化と建築エレメントの工場生産化による施工 の経済化という重大なるのをるている。諸外国にはす でにいくつかの製品があり、日本でもそれらの生産は始 まつているが、表板とコアとの組合わせの可能性汕多数 あり(1)、乙れらを組織的偪試作し、検討する必要があ る。ここで法特に軽量な $2 ， 3$ のコア材料を用い、これ 亿各種ボードや金属板を接着したパネルを武作し、その 曲げ性能を実験によつてたしかめた。まず小型試験体に よつて奏験し、その結果等を勘案して実大試験体の曲げ 試験を行なつた。これらは主として壁体への利用在想定 しているが、屋根または床に適用し得るものも含まれて いる。

$\S 2$. 小型試験体の実験

2.1 試験体の構成 第1表に示すようにコアとして ペーパーハニカムと泡スチレン樹脂の 2 種を用い、表板

第 1 表 小型試験 体 の構成

\begin{tabular}{|c|c|c|c|c|c|}
\hline 垱験体記号 & 表 板 (厚さ $\mathrm{mm}$ ) & コア 材 料 & $\begin{array}{c}\text { 全 体 擪 } \\
\mathrm{mm}\end{array}$ & $\begin{array}{c}\text { 重量(票均) } \\
\mathrm{kg}\end{array}$ & 見か心比雷 \\
\hline PH 640 & 2 類 合 板 $(6.0)$ & ペーパーハニカム & 52 & 1.49 & 0.16 \\
\hline $\mathrm{PH} \quad 440$ & 2 類 合 板 $(4.0)$ & （クラフト綎基材、 & 48 & 1.08 & 0.13 \\
\hline PH & 2 類 合 板 $(3.0)$ & フェノール樹脂付着 & 46 & 0.88 & 0.11 \\
\hline $\mathrm{BH} \quad 340$ & ハードポート゚S (3.5) & 率 10〜13\%、胃加付 & 47 & 1.54 & 0.18 \\
\hline АH 140 & アルミニウム板 $(1.0)$ & 比重 $0.023 \sim 0.028$ ) & 42 & 1.17 & 0.15 \\
\hline 433 & 2 類 合 板 $(4.0)$ & & 41 & 1.07 & 0.14 \\
\hline 823 & 石こ 5 ボード $(8.0)$ & 泡スチレン樹脂（見 & 39 & 3.05 & 0.43 \\
\hline 629 & 石こ 5 ボード(6.0) & 加け比量 $0.015 \sim$ & 41 & 2.15 & 0.29 \\
\hline $\mathrm{CS}$ & 石綿スレート (3.0) & 0.025 、白色) & 46 & 2.28 & 0.28 \\
\hline AS 138 & アルミニウム板 $(1.0)$ & & 40 & 1.16 & 0.16 \\
\hline
\end{tabular}

（両面同一種類）に各種ボードを 使つたもの10 種類を試作した。 接着剤はコアと表板の組合せ汇適 したものをそれぞれ選んだが、実 用上からもつ之も経済的な酰酸ビ ニル系抢よび尿素樹脂系のものを 使つている。コアと表板との厚さ の比は曲げ理論上の最適值がある が(2)、それによると表板はこてに

* 横浜国立大学助教授 工博
第 2 表 小型試験体の試験結果（平均值）

試作したものよりかなり薄いものでよいととになる。し かし実用上は純料䏸げのほかに局部压縮や衝撃などに対 する抵抗力考荐党、材料の市販厚さ寸法を考光るとこの 表の範囲になる。試験体の寸法は $20 \times 90 \mathrm{~cm} \times$ (厚さ) て、、各種類 4 枚宛作製した。

2.2 試験方法 試験体はスパン $81 \mathrm{~cm}$ に支党、そ $の 3$ 等分点に 2 点荷重を加光た。荷重点と支点はともに 径 $3 \mathrm{~cm}$ の鋼棒でが、これらのめり込みを防ぐために特 硬ハードボードの带板を介した。陚験機はスプリングレ バー式 (1 ton) パネル曲げ武験機で、たわみは $1 / 100 \mathrm{~mm}$ ダイヤルゲージで、中央および何重点下で測定した。

2.3 試験結果曲げ破瀤係数は、パネル全体厚によ る断面係数を用いて計算し、また最大せん断応力度は同 せくパネル全断面積をもとにして計算した。各種類別の 平均值は第 2 表の通りである。ての結果によると、ま ず、コアについては、ハニカムの活うが泡スチレンより 強い。乙れは後者のせん断耐力が弱いためと表板との接 着力が不足するものがあるためである。それは最大せん 断応力度を比較してもわかるし、破壞状態もてれを立証 している。表板については、ハニカムパネル群で比較す ると、アルミニウム板が強く、ついでハードボード、合 板の順になる。この傾向はコアの不安定な泡スチレンコ アのパネルについては成立しな い。つぎに表板の厚さの関係は、 合板八ニカムパネルについていら と、合板愿さを増してもパネルの 強さははとんど向上しない。これ は前述のように表板の厚さは 3 mmでもすでにじうぶんであると いう理論を裹書きするものであ り、またコアと表板との接着力が

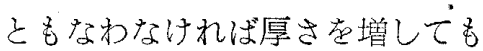

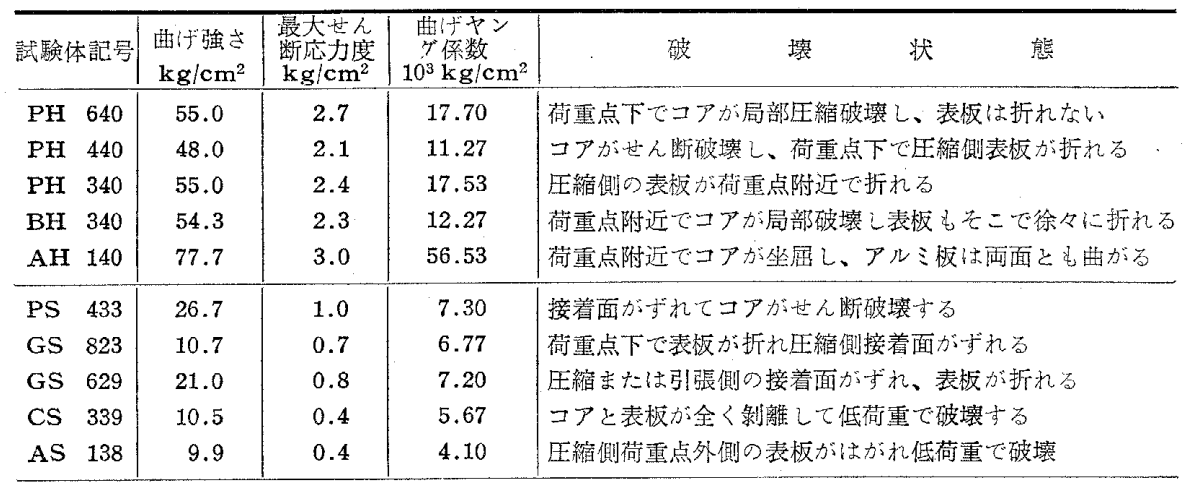




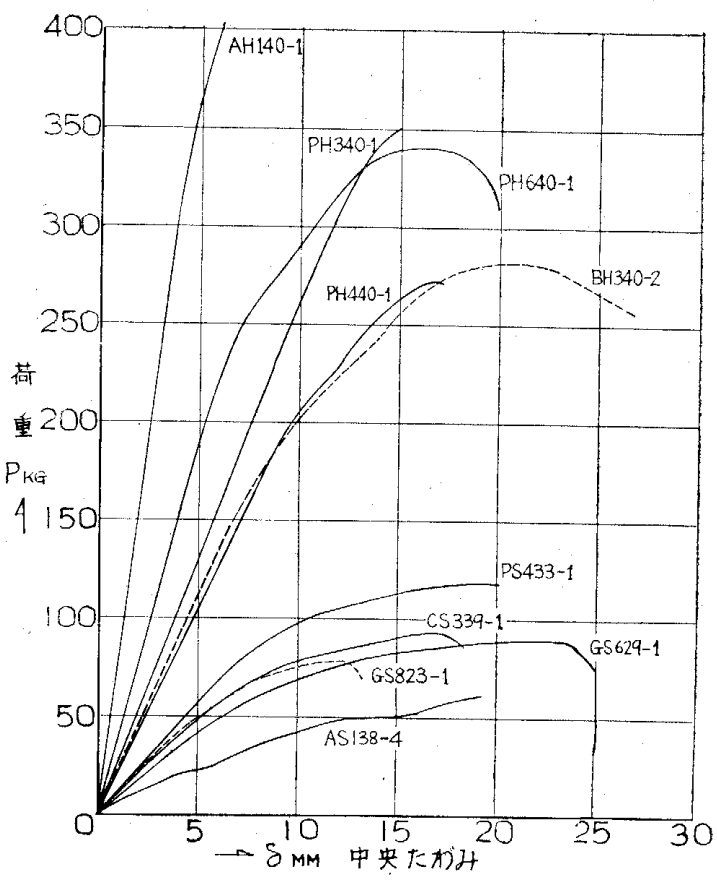

第 1 図 小型試験体の荷重一たわ女図
については、大体曲げ強さの大きいものほどヤング係数 も大きい傾向にある。表板の剛性が十分にパネルに生か されるためには接着面やコアのけん断剛性が必要である ことがよくわかる。表板が同一種類の場合、その厚さに よるパネルのヤング率の差異はあまり認少られない。ヤ ング係数のばらつき、およびャング率とパネル重量との， 関係は、曲げ強さの場合と同じような傾向にある。

破堙状態については、同じく第 2 表に述べてあるサ ンドイッチパネルでは表板に先だつてコアが破壊しない ととがのぞましい。コアの破壤は荷重点下の局部圧縮に よるものと、せん断によるものとがある。前者は表板が 薄いアルミ板の場合に見られ、接着面はよくついている ものが多い。いわば健全な破壊である。後者はコア自体 のせん断耐力の不足か、接着層でずれてはがれる場合で ある。この現象はことに泡スチレンコアにおいて顕著 で、ての材料の本質的な弱点である。コアが健全である 場合、表板は、合板やハードボードでは荷重点下の压縮 側が折れることが多く、石綿スレートや石とうボードで

效果のないことは石こうボード

十泡スチレンのパネルについて

みてもわかる。また、これらの パネルの同一種類間での強さの 价つきもかなり認められるも のもあるが、そのすべてが接着 不良と考光られる。したがつて サンドイッチパネルの強さは、 ここにあらためていうまでもな く、表板とコアとの強固な結び つきが前提となる。各パネルの

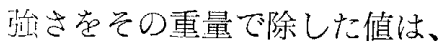
アルミ板十八ニカムが最大で 65.9 示し、これ机ついで $3 \mathrm{~mm}$ 合板十八二カムでは 48.9 であ り、合板が厚くなるとこの值は 蔵し、 $6 \mathrm{~mm}$ のものは 36.9 て ある。泡スチレンコアのものは 前述の通り、曲げ搔さが少ない ので梳さ/重量の值は小さく、 4.6〜25.0 亿止まつている。

曲げャング係数は第 1 図に示 す上うな各試験体の荷重変形図 から求め、パネルとしての相当 曲げヤング係数として同じ第 第 2 表に示してあるが、との場 合も八ニカムパネル群がすぐれ ている。これはコア自体および 接着面のせん断剛性の差異によ るものとみられる。表板の種類
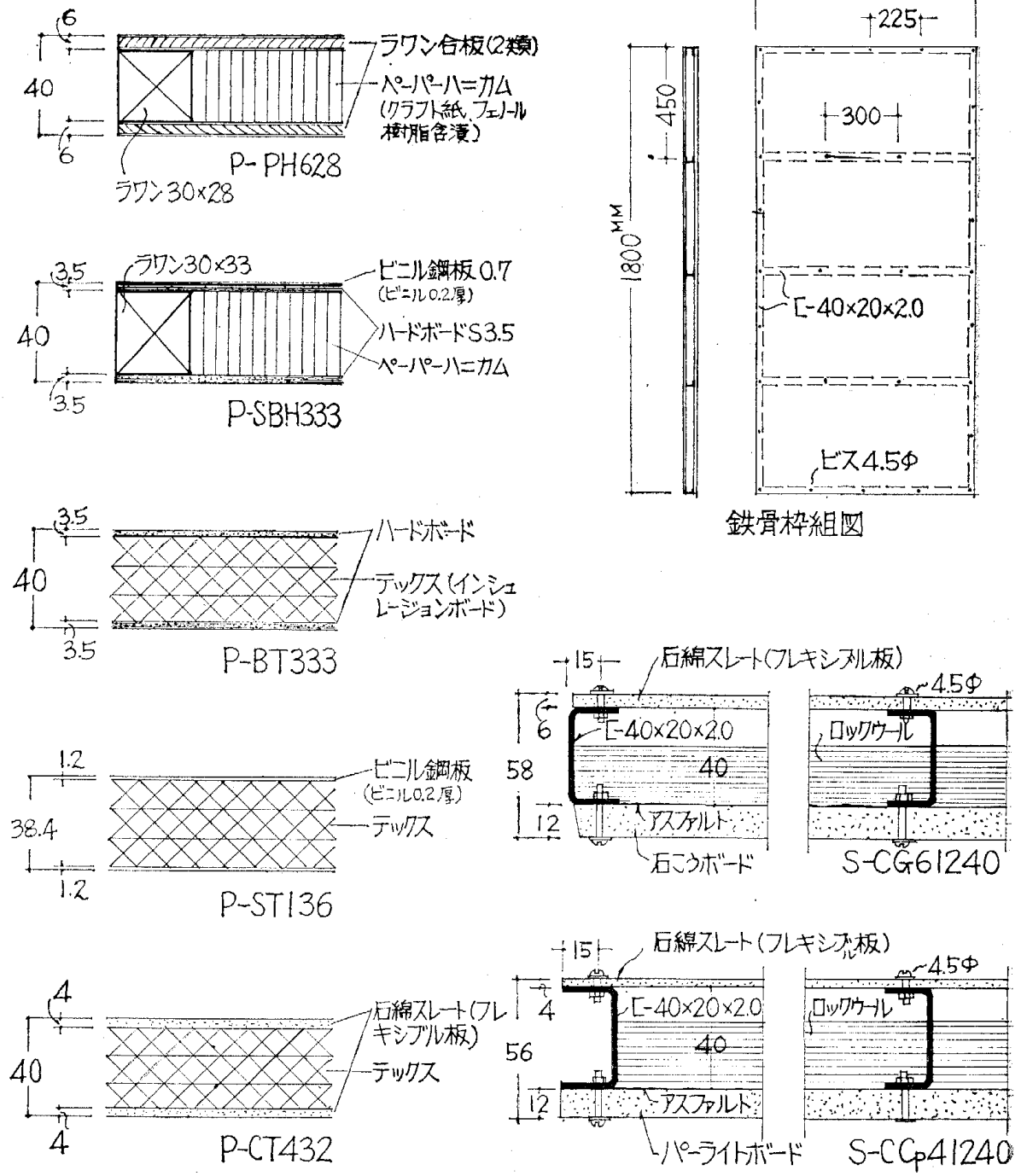

第 2 図実大試験体（単位 $\mathrm{mm}$ ) 
は引張側が破断するととが多い。 アルミ板怡荷重点がめり込みつつ ・曲方るのであつて折損する現象は ない。

\section{§3． 実大パネルの曲げ試験}

3.1 試験体の試作 前述武験 において、サンドイッチパネルで は、ことに表板とコアとの㧧固な 結合が必要であるととが明らかと なつた。ての点は実大パネルにつ いても特に懸念されるとてろであ り、重悋てての実験を行なつた。 すなわち、巾 $90 \mathrm{~cm}$, 長さ $180 \mathrm{~cm}$ のパネルとし、その厚さは 4 5 $\mathrm{cm}$ とした。これらは壁体用とし

\begin{tabular}{|c|c|c|c|c|c|c|c|}
\hline 詿験体記号 & No. & $\begin{array}{c}\text { 重 量 } \\
\mathrm{kg}\end{array}$ & \begin{tabular}{|l|} 
曲姑強さ \\
$\mathrm{kg} / \mathrm{cm}^{2}$
\end{tabular} & 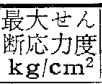 & 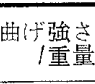 & $\begin{array}{l}\text { 相当曲 } \\
\text { 俰数 } \\
10^{3} \mathrm{~kg} / \mathrm{cm}^{2}\end{array}$ & 備 \\
\hline \multirow{2}{*}{ P-PH 628} & 1 & 13.4 & 110.7 & 1.5 & 8.3 & 28.6 & \\
\hline & 2 & 13.4 & 131.9 & 1.8 & 9.8 & 24.5 & \\
\hline \multirow{2}{*}{ P-SBH 333} & 1 & 21.1 & 153.8 & 2.0 & 7.3 & 36.4 & ハードポード面上り加重 \\
\hline & 2 & 21.0 & 123.3 & 1.6 & 5.9 & 33.9 & ビ二ル銅柆面より加重 \\
\hline \multirow{2}{*}{ P-BT 333} & 1 & 30.5 & 69.5 & 1.0 & 2.3 & 14.8 & \\
\hline & 2 & 30.2 & 67.7 & 1.0 & 2.2 & 13.7 & \\
\hline \multirow{2}{*}{ P-ST 136} & 1 & 44.2 & 58.3 & 0.8 & 1.3 & 65.5 & \\
\hline & 2 & 43.9 & 52.8 & 0.8 & 1.2 & 68.7 & \\
\hline \multirow{2}{*}{ P-CT 432} & 1 & 31.1 & 19.6 & 0.3 & 0.63 & 19.8 & \\
\hline & 2 & 30.9 & 23.3 & 0.4 & 0.75 & 22.2 & \\
\hline \multirow{2}{*}{ S-CG 61240} & 1 & 54.5 & 28.0 & 0.6 & 0.50 & 11.3 & 石こうボード面上り加重 \\
\hline & 2 & 54.0 & 25.1 & 0.5 & 0.47 & 13.5 & 石綿スレート面上り加重 \\
\hline \multirow{2}{*}{ S-CCp 41240} & 1 & 59.0 & 32.2 & 0.6 & 0.55 & 10.0 & パーライトボード面より加重 \\
\hline & 2 & 57.5 & 37.0 & 0.8 & 0.64 & 12.5 & 石綿スレート面より加重 \\
\hline
\end{tabular}

て考光ているが、従来の壁厚は大壁では 12〜15 cm あ るがその内部 9 12 cm は中空であつて、必らずしもそ れだけの空気層は要らず、真壁では $6 \sim 8 \mathrm{~cm}$ である が、とこで注特に軽量化と経済性を祆らい、この厚さで 十分と考光たものである。コアとしては今回は、ペーパ 一ハニカムまたはテックスを用い、表板には合板、ハー ドボード、ビニル鋼板、石綿入トレートなどを用いた。 八ニカムパネルでは実用上、側面周国には木村枠をつけ る必要があるのでての場合もそれにしたがいラワン材を 国らした。接着㓮は前述実験と同様、酢酸ビニル系等を 用いた。また、とれらのサンドイッチパネルと比較のた め、鉄骨枠の両面に石綿スレート、パーライトボード、 石こうボード、などをどス止めしたパネル各併せて試作 した。これらのパネルの構成と厚さは第 2 図の通りであ る。同一種類のパネルは 1 枚または 2 枚宛試験した。

3.2 試験方法 パネルを $150 \mathrm{~cm}$ 間に支元、中央集 中荷重を加すえた。試験機および武験方法はすべて前回

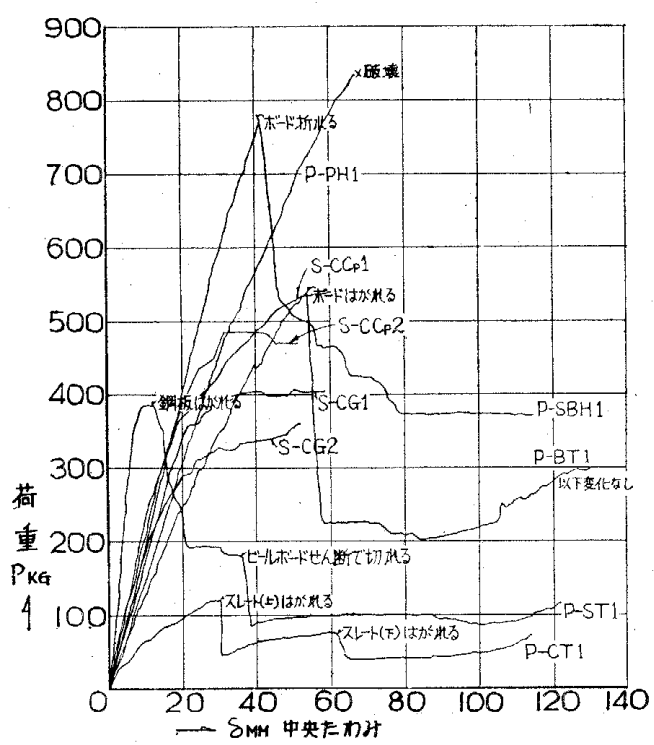

第3 図 実大試験体の荷重一たわ多図
試験に準ずる。今回のパネルは表裏で材料の異なるもの が 3 種類あるが、それらはすべて別々の試験体により、 表および裏から荷重を加わえて試験した。また今回は各 パネルにつき、100 kg，200 kg（場合により $300 \mathrm{~kg}$ ）ま での往復荷重学加えてヒステリシスを検した。その結果 はここでは省略するが、大体に扔いて deviation は少な く、残留変形も $1 \mathrm{~mm}$ 以内のものが多かつた。

3.3 試験結果曲げ強さは破壊荷重と、パネル全体 厚にもとずく断面係数から計算した。鉄骨枠パネルでは その破萝荷重は最大荷重よりわずか低くなつているが、 これも破壊時荷重で計算した。各パネルの代表試験体の 荷重一中央たわみ図は第3図の通りである。各試験体の 相当曲げヤング係数は全体厚にもとずく断面 2 次モーメ ントによつて計算した。乙れらの值は第 3 表に示す通り である。各パネルの破壊状態は一覧表として第 4 表に示 した。

第 4 表 実大試験体の破壞状態

\begin{tabular}{|c|c|}
\hline 試験休記号 & 状 \\
\hline P-PH 628 & 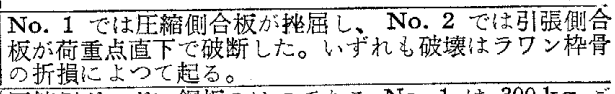 \\
\hline P-SBH 333 & 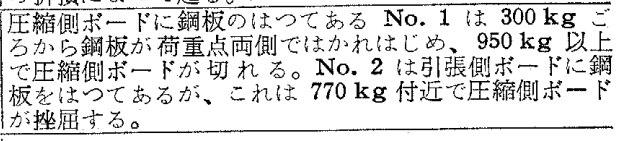 \\
\hline P-BT 333 & 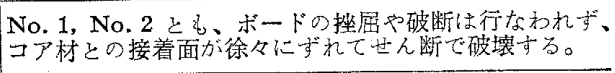 \\
\hline P-ST 136 & 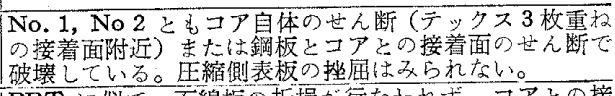 \\
\hline $\mathrm{P}-\mathrm{CT} 432$ & 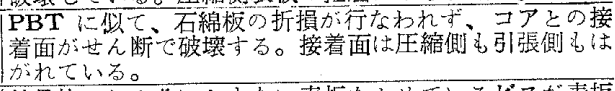 \\
\hline $\begin{array}{l}\text { S-CG } 61240 \\
\text { 石こうボード面 } \\
\text { 何重 }\end{array}$ & 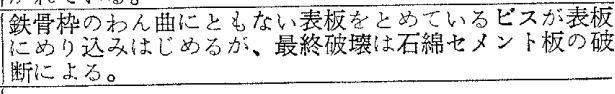 \\
\hline $\begin{array}{l}\text { S-CG } 61240 \\
\text { 不綿スレート面 } \\
\text { 荷重 }\end{array}$ & $\begin{array}{l}\text { 左縮側の石綿セメント板は破壊せず、引張側の石こうボ } \\
\text { 一ドが破断する。 }\end{array}$ \\
\hline 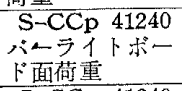 & 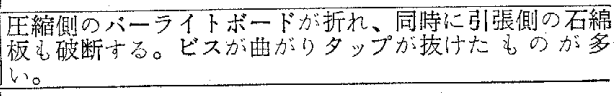 \\
\hline $\begin{array}{l}\text { S-CCp } 41240 \\
\text { 石綿ス } \\
\text { 荷重 }\end{array}$ & $\begin{array}{l}\text { 引張側のバーライトボードが折れ、压縮僛の石綿板はた } \\
\text { bんだ出ま折れない。 }\end{array}$ \\
\hline
\end{tabular}




\section{\$4. 考察}

小型試験体による実験についてはその試験結果の項で 考察を述べたので、こてでは主として実大パネル試験体 についての考察を述べるが、サンドィッチパネル全般に ついの見解にも触れるとととする。

4.1 曲げ強さについて これらのパネルの中ではハ ニカムコアの場合がすぐれている。実大試験体では周囲 に入つているラワン枠が褔強の役割を果たしているとと は明らかだが、小型武験体の結果をみてもやはりハニカ ムコアがすぐれているととがわかる。とれは結局、八ニ カムと表板との接着がきわめて強固であるととを意味し ている。その点ではテックスのコアはせん断に弱く、接 着面でもはが机ることが多い。また鉄骨枠の場合もあま り強くない。これは当然予測されたととだが、表板との 接合ビスが州がることや、ずれて表板にめり込むとと、 および鉄骨そのものの嗍性、酎力が八ニカムサンドイッ チ波ばないためである。ビス留め間隔在現状よりもつ とせばめれば強度の向上は望めるかもしれないが、その 留付操作はかなりめんどうで実用的ではない。最大せん 断応力度をくらべても、てれらのコア、鉄骨枠の優劣は 明らかである。表板の種類による強さの比較は、合板が かなりすぐれている。ビニル鍓板を上貼りしたハードボ ードのパネルと比較しても見劣りがしない。ハードボー ド、ビニル鋼板、石線セメント板の3者については、コア であるテックスの接着せん断力か溺いので、てれらの表 板の強さが完全に発揮されていないからこしでは比較に ならない。芑しろ接着力の比較になつており、その点で はハードボードがよく、石綿スレートが一番悪い。鉄骨 枠にとりつけた各種の不然ボードの比較も上述と同様な 理由であまり明らかでないが、やはり石しうボードを含 导ものは弱くなつている。各パネルの曲げ強さを重量で 割つた值㴊揭表に示してあるが、や沈りハニカムコア がすぐれ、表板に石綿スレートを使つたものや鉄骨枠の パネルはその重量の割に強さは大きくない。つぎに小型 試験体と実大試験体との比較であるが、共通構成をもつ $6 \mathrm{~mm}$ 合板一八ニカムパネルで比較すると、実大試験体 のほうが曲げ強さとして 2 倍以上の值を得ている。これ はラワン材の周国枠が補㤝の役目をしていることも否定 できないが、スパンに対してけが大きい実大パネルでは 版としての曲げ強さになつているためと法えられる。

4.2 パネルの相当ヤング係数 八ニカムコアとデッ クスコアとの場合では大差がない。しかしコアそのもの のヤング係数は後者がはるかにすぐれているから、ほん とうはテックスコアのパネルのほうがすぐれているはず で、そうでないのは表板との接着部のせん断剛性に難点
があると思われる。鉄骨染の場合は、ここではほとんど 鉄骨の剛性できまるために他のサンドイッチパネルのよ うに表板の協力が期待できないので用性は少ないのは不 利である。つぎに表板による影響であるが、鋼板を表板 としたものは風性が高い。これは当然なととで、接着面 がもつと強固であれば、もつと高い剛性が得られ、した がつて相当ヤング係数も大きくなるはずである。また合 板を表板とするものもかなりよく、ハードボードよりも 好結果等ているととは前述の小型試験体の場合と一致 している。石綿スレートの表板は、接着が完全であれば もつと剛性は大きいはずですり、やはりコアおよび接着 面のせん断剛性が大きく影響している。つぎに重量とヤ ング率との関係蛙、大体曲げ強さの場合と同じような傾 向学示している。合板十八ニカムパネルや鋼板十ハード ボード十ハニカムなどの陚験体がよい值を示しているこ とは、判性の面からみてもこれらのパネルが実用的であ るととを立証している。鉄骨枠パネルは、その重量にく らべて案外㓮性が少ないととに注目しなければならな い。乙れは鉄骨乾式構造の岡性を類推させるもので、こ の実験結果によつてもこの点の重要性があらためて誑識 されね施らなと思う。つまりビスで留为付けた程度 のボード類では鉄骨構造の㓣性を增すにはあまり効果が ないのではないかということである。もつとも、てれは 面外剛性についてであつて、面内剛性についての結果で はない。

4.3 破壊状態とれらのパネルについては、表板の

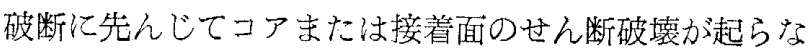
いことが望ましい。その点で、ハニカムコアはかなり理 想に近いものである。テックスコアについても接着面の 破猿状態军くわしくしらべてみると、表板がハードボー ドの場合も石綿スレートの場合もかなりよく接着してい るのだが、テックスの部分が接着面のすぐ近くでむしら れている。これは合板でいういわゆる「木部破断率」が かなり高く、その意味で、簃密にはコアそのもののせん 断酎力がこの種のパネルの曲げ菭さを支配するものと考 えることもできる。もちろんそれには表板とコアの組合 せにもつとも適し、しかも経済的小接着郕と接着法か淀 められなければならない。今四の奏験を通し、この点を 特に痛感するものである。なお、との研究は、日本俥量 鉄骨建築協会の壁体研究委員会炤和 35 年度報告畫の一 部である。

[注]

（1）飯塚：軽量鉄骨建築各部構法（鉄骨店舗付住宅」鋼材 俱楽部 1955 年)

（2）飯塚：サンドイッチパネルの強さと断熱性（建築と社 会 1956 年 10 月) 